\title{
Antibiotic susceptibility of enterococci isolated from traditional fermented meat products
}

\author{
J. Barbosa, V. Ferreira, P. Teixeira* \\ CBQF/Escola Superior de Biotecnologia, Universidade Católica Portuguesa, Rua Dr. António Bernardino de Almeida, 4200 - 072 Porto, Portugal
}

\begin{abstract}
A B S T R A C T
Antibiotic susceptibility was evaluated for 182 Enterococcus spp. isolated from Alheira, Chouriça de Vinhais and Salpicão de Vinhais, fermented meat products produced in the North of Portugal. Previously, a choice was made from a group of 1060 isolates, using phenotypic and genotypic tests. From these, 76 were previously identified as Enterococcus faecalis, 44 as Enterococcus faecium, one as Enterococcus casseliflavus and 61 as Enteroccocus spp. In order to encompass several of the known chemical and functional classes of antibiotics, resistance to ampicillin, penicillin G, ciprofloxacin, chloramphenicol, erythromycin, nitrofurantoin, rifampicin, tetracycline and vancomycin was evaluated. All the isolates were sensitive to antibiotics of clinical importance, such as penicillins and vancomycin. Some differences in Minimal Inhibitory Concentrations (MICs) of antibiotics, could be associated with the enterococcal species.
\end{abstract}

Keywords:

Alheira

Salpicão de Vinhais

Chouriça de Vinhais

Fermented meat products

Enterococci

Antibiotic susceptibility

\section{Introduction}

Enterococci are resistant to a wide variety of antibiotics. This feature allows enterococci to survive in the hospital environment, where antibiotics are used, and provides the opportunity for dissemination of resistant organisms (Murray, 1990; Leclercq, 1997). This resistance can be both intrinsic, mediated by genes located on the chromosome - a characteristic present in almost all the strains of enterococci (Moellering and Krogstad, 1979) - or acquired, mediated by genes residing on plasmids or transposons (Murray, 1990). Resistance to cephalosporins, sulphonamides, lincosamides, many $\beta$-lactams and low levels of aminoglycosides, is recognized as intrinsic (Moellering, 1990; Murray, 1990; Leclercq, 1997; Morrison et al., 1997). The acquired genetic determinants confer resistance to all classes of antimicrobials, including chloramphenicol, tetracyclines, erythromycin, rifampicin, ampicillin and glycopeptides. The main concern is that the genes coding for all these antibiotic resistance traits could be transferred by pheromone mediated, conjugative plasmids or transposons to other enterococci or even to more virulent pathogens (Morrison et al., 1997; Schwarz et al., 2001).

The resistance to glycopeptides is a clinically relevant characteristic (Endtz et al., 1999). Almost all Gram-positive bacteria are

\footnotetext{
* Corresponding author. Tel.: +351 225580001; fax: +351 225090351.

E-mail address: pcteixeira@esb.ucp.pt (P. Teixeira).
}

susceptible to their activity. On the contrary, glycopeptides are relatively large water-soluble molecules that cannot penetrate the lipid outer membrane of Gram-negatives (Houben, 2003). Six phenotypes have been reported for enterococci: vanA, vanB, vanC (Moellering, 1991; Moellering and Gold, 1996), vanD (Arthur et al., 1993), vanE (Fines et al., 1999) and, recently described, vanG (McKessar et al., 2000).

Antibiotic-resistant enterococci have been found in meat products, dairy products and ready-to-eat foods (Corpet, 1998; Quednau et al., 1998; Teuber et al., 1999; Baumgartner et al., 2001; Gomes et al., 2008; Koluman et al., 2009). In several cases, isolates were resistant to one or more antibiotics including bacitracin, chloramphenicol, erythromycin, gentamicin, penicillin, rifampicin, streptomycin and tetracycline (Son et al., 1999; Teuber et al., 1999; Hayes et al., 2004).

Some authors showed the occurrence of vancomycin-resistant enterococci (VRE) on food of animal origin (Klein et al., 1998; Van den Braak et al., 1998; Gomes et al., 2008; Sabia et al., 2008; Koluman et al., 2009). There is strong evidence that this resistance was developed through the use of the glycopeptide avoparcin in animal production in the European Union (EU). This is probably responsible for the increased prevalence of VRE in non-hospitalized human populations of the EU. The glycopeptide avoparcin was banned in Europe in 1997 and its manufacture stopped in 1999, decreasing the prevalence of VRE in animals and human faecal specimens (Del grosso et al., 2000; Borgen et al., 2001). 
The presence of enterococci in fermented foods is controversial. Although they exhibit interesting technological properties they are recognized as opportunistic pathogens (Ogier and Serror, 2008). Antibiotic resistance among enterococci isolated from food is also a cause of concern. Hummel et al. (2007) reported the presence of resistance genes and transposon integrase genes associated with transferable resistances in Enterococcus spp. isolated from foods.

The aim of this work was to evaluate the antibiotic susceptibility of enterococci isolated from traditional fermented meat products, produced in the north of Portugal, i.e. Alheira, Salpicão and Chouriça de Vinhais.

\section{Material and methods}

\section{Origin of isolates}

One thousand and sixty isolates of presumptive enterococci Gram-positive cocci, catalase and oxidase negative, presenting characteristic colonies on Bile Aesculin Azide Agar (BAAA) - were investigated. Strains were previously isolated in our lab, between September 2003 and September 2005, from Alheira (749), Salpicão de Vinhais (157) and Chouriça de Vinhais (154) manufactured by 16 producers (Ferreira et al., 2006; Ferreira et al., 2007). Samples were collected from various stages of production (in the processing plants) and final products (supermarkets and Feira do Fumeiro).

\section{Growth and storage conditions}

Isolates were grown on Brain Heart Infusion Agar (BHIA) (Lab M, Lancashire, United Kingdom) at $37^{\circ} \mathrm{C}$ for $24 \mathrm{~h}$ and stored at $-80^{\circ} \mathrm{C}$ in Brain Heart Infusion Broth (BHIB) containing 30\% (v/v) of glycerol (Sigma, Steinheim, Germany), and sub-cultured twice before use in assays.

\section{Phenotypic characterization}

Growth of presumptive enterococci was evaluated in microtitre plates under different conditions of temperature $\left(10^{\circ} \mathrm{C}\right.$ and $\left.45^{\circ} \mathrm{C}\right)$, high $\mathrm{pH}(9.6)$ and in the presence of $6.5 \%(\mathrm{w} / \mathrm{v})$ of $\mathrm{NaCl}$, according to Devriese et al. (1993). Increased turbidity was indicative of growth of the isolates. For each microtitre plate, non-inoculated medium was used as a negative control. Isolates grown in BHIB at $37^{\circ} \mathrm{C}$ for $24 \mathrm{~h}$ were used as positive controls. All the tests were carried out in duplicate.

\section{Typing of isolates}

Random Amplified Polymorphic DNA Polymerase Chain Reaction (RAPD-PCR) was the method selected for typing the isolates. The primers used for the RAPD-PCR reactions were M13 (MWG Biotech AG, Ebersberg) (5'- GAG GGT GGC GGT TCT -3') and D8635 (MWG Biotech AG, ) (5'- GAG CGG CCA AAG GGA GCA GAC - $3^{\prime}$ ) as described by Andrighetto et al. (2001). The bacterial strain used as reference was Enterococcus faecalis ATCC 29212.

\section{Extraction of DNA}

This method was described by Destro et al. (1996) and optimized in ESB Food Microbiology laboratory for some Gram-positive bacteria, including enterococci. One colony of each isolate, grown overnight at $37^{\circ} \mathrm{C}$ on BHIA, was resuspended in $3 \mathrm{ml}$ of BHIB and incubated overnight at $37^{\circ} \mathrm{C}$. One $\mathrm{ml}$ of each cellular suspension was transferred to an eppendorf tube and centrifuged at $13700 \mathrm{rpm}$ at $4{ }^{\circ} \mathrm{C}$ (Rotina 35R, Hettich, Germany) for $5 \mathrm{~min}$. The supernatant was discarded and the pelleted cells were resuspended in $1 \mathrm{ml}$ of saline water $(0.9 \%(\mathrm{w} / \mathrm{v}))$ and centrifuged at $13700 \mathrm{rpm}$ for $5 \mathrm{~min}$, twice. The final cell pellets were resuspended in $50 \mu$ l of sterile water and the eppendorf tubes were placed in boiling water for $15 \mathrm{~min}$.

\section{PCR amplification}

PCR amplifications were performed in a ThermoCycler (MyCycler $^{\mathrm{TM}}$, Thermocycler Firmware, Bio-Rad, Richmond, CA) in $0.2 \mathrm{ml}$ reaction tubes each with $25 \mu \mathrm{l}$ of mixtures composed of the primer M13: $0.99 \mathrm{pM}, 150 \mu \mathrm{M}$ of deoxynucleoside triphosphates (dNTPs, ABGene, Surrey, United Kingdom), $1 \times$ of PCR Buffer (MBI Fermentas, Mundolsheim, France), $2.5 \mathrm{mM}$ of $\mathrm{MgCl}_{2}$ (MBI Fermentas), $2 \mathrm{U}$ of Taq polymerase (MBI Fermentas) and $1 \mu \mathrm{l}$ of extracted solution of enterococcal DNA. For the primer D8635 the mixture was composed of $0.88 \mathrm{pM}$ of primer, $200 \mu \mathrm{M}$ of dNTPs, $1 \times$ of PCR Buffer, $2.5 \mathrm{mM}$ of $\mathrm{MgCl}_{2}, 2 \mathrm{U}$ of Taq polymerase and $1 \mu \mathrm{l}$ of extracted solution of enterococcal DNA. PCRs were performed under the following conditions: initial cycle of $94^{\circ} \mathrm{C}$ for $2 \mathrm{~min}$; 35 cycles of $94{ }^{\circ} \mathrm{C}$ for $1 \mathrm{~min}$, annealing temperature of $46.9^{\circ} \mathrm{C}$ for $1 \mathrm{~min}, 72^{\circ} \mathrm{C}$ for $1.5 \mathrm{~min}$; a final extension step of $72{ }^{\circ} \mathrm{C}$ for $10 \mathrm{~min}$ and thereafter cooled to $4{ }^{\circ} \mathrm{C}$. For each PCR, a negative control (sample without template) and a positive control (sample with DNA from strain $E$. faecalis ATCC 29212) were included.

\section{Gel electrophoresis}

All amplification products were combined with $3 \mu$ of loading buffer (Bio-Rad) and $15 \mu \mathrm{l}$ of these mixtures were applied to a submerged horizontal agarose gel (Seakem ${ }^{\circledR}$ LE Agarose, Rockland, ME, USA, 1.2\% (w/v)) in $1 \times$ TAE Buffer (40 mM Tris, $20 \mathrm{mM}$ acetic acid and $1 \mathrm{mM}$ EDTA, pH 8.3; Bio-Rad) containing $0.5 \mu \mathrm{g} / \mathrm{ml}$ of ethidium bromide. Electrophoretic separation was at $80 \mathrm{~V}$ for $2 \mathrm{~h}$ and, on each gel, a molecular weight marker (100 bp PCR ladder, Bio-Rad) was included at two positions. The gels were photographed on a UV transilluminator (GelDoc2000, Bio-Rad) and image analysis was accomplished using Quantity One ${ }^{\circledR}$ software (Bio-Rad).

\section{Statistical analysis}

RAPD-PCR profiles were subsequently analyzed using the Gel Compar II Software (Applied Maths, Kortrijk, Belgium). Calculation of the similarity of the bands profiles and grouping of the RAPDPCR patterns were based on the Pearson's coefficient and agglomerative clustering was performed with the unweighted pairs group matching algorithm (UPGMA; Nilsson et al., 1998; Psoni et al., 2006).

\section{Selection of isolates}

Based on the combined dendrogram obtained by the RAPD-PCR patterns, isolates were arbitrarily selected for further studies by visual inspection of all the identical profiles.

\section{Identification of enterococcal isolates}

\section{Identification and detection of van genes by multiplex-PC}

Identification of isolates at species level and the detection of van genes were performed by multiplex-PCR according to Dukta-Malen et al. (1995), with some modifications. Total DNA was extracted by the guanidium thiocyanate method (Pitcher et al., 1989) and PCR amplifications were performed in a ThermoCycler (Bio-Rad) in $0.2 \mathrm{ml}$ reaction tubes each with $25 \mu \mathrm{l}$ of mixtures using $0.5 \mathrm{mM}$ of each primer (all purchased from MWG Biotech AG), $0.1 \mathrm{mM}$ of dNTPs (ABGene), $1 \mathrm{X}$ of PCR Buffer (MBI Fermentas), $2 \mathrm{mM}$ of $\mathrm{MgCl}_{2}$ (MBI Fermentas), 1U of Taq polymerase (MBI Fermentas) and $100 \mathrm{ng} / \mu \mathrm{l}$ of enterococcal DNA. Amplification reactions were performed under the following conditions: initial cycle of $94^{\circ} \mathrm{C}$ for $2 \mathrm{~min}$; 30 cycles of $94^{\circ} \mathrm{C}$ for $1 \mathrm{~min}$, annealing temperature of 
$51.6^{\circ} \mathrm{C}$ for $1 \mathrm{~min}, 72{ }^{\circ} \mathrm{C}$ for $1 \mathrm{~min}$; a final extension step of $72{ }^{\circ} \mathrm{C}$ for $10 \mathrm{~min}$ and thereafter cooled to $4{ }^{\circ} \mathrm{C}$. For each PCR a negative control (sample without template) and a positive control were included. Gel electrophoresis was done as described above in 2.4.3.

\section{Genus-specific PCR}

For isolates not identified at species level, a PCR assay for the identification of the genus Enterococcus was carried out according to the method described by Ke et al. (1999). Total DNA was extracted according to Pitcher et al. (1989) by using the guanidium thiocyanate method. E. faecalis ATCC 29212 was used as a positive control and the primers used were EntF (MWG Biotech AG) (5'-TAC TGA CAA ACC ATT CAT GAT G $-3^{\prime}$ ) and EntR (MWG Biotech AG, Ebersberg) (5'- AAC TTC GTC ACC AAC GCG AAC - $\left.3^{\prime}\right)$.

\section{MIC determination}

The minimum inhibitory concentration - MIC $(\mu \mathrm{g} / \mathrm{mL})$ of nine antibiotics was determined for all isolates by the agar microdilution method, according to the National Committee for Clinical Laboratory Standards (NCCLS, 2004). Each test was carried on MullerHinton agar (MHA) (BioMérieux, Marcy l'Etoile, France) with cations adjusted for penicillin G (Sigma) and ampicillin (Fluka, Steinheim, Germany) and on MHA for the other seven antibiotics vancomycin and chloramphenicol (both from Fluka), nitrofurantoin (Sigma), erythromycin, tetracycline, ciprofloxacin and rifampicin (kindly supplied by the company Labesfal, Tondela, Portugal). Antibiotic concentrations ranged from 0.03 to $512 \mu \mathrm{g} / \mathrm{ml}$. Table 2D (MIC Interpretative Standards ( $\mu \mathrm{g} / \mathrm{ml}$ ) for Enterococcus spp.) in NCCLS (2004) was consulted in order to classify the isolates according to their susceptibility (sensitive, intermediate or resistant)

Each experiment was performed in duplicate and all the isolates were grown on plates of MHA and MHA with cations adjusted with no antibiotic. The quality control strains E. faecalis ATCC 29212 and Staphylococcus aureus ATCC 29213 were used to monitor the accuracy of MICs (NCCLS, 2004).

Screening-test for high-level aminoglycoside resistance and vancomycin resistance

Isolates showing an intermediate resistance to vancomycin (MICs in the range of $8-16 \mu \mathrm{g} / \mathrm{ml}$ ) were submitted to a screeningtest according to NCCLS (2004); three antibiotics were used at different concentrations: gentamicin at $500 \mu \mathrm{g} / \mathrm{ml}$, streptomycin at $2000 \mu \mathrm{g} / \mathrm{ml}$ and vancomycin at $6 \mu \mathrm{g} / \mathrm{ml}$, all on BHIA. All experiments were done in duplicate and the strains $E$. faecalis DSMZ 12956 (resistant to all the antibiotics) and E. faecalis ATCC 29212 (susceptible to all the antibiotics) were used as controls.

\section{Results and discussion}

The 1060 isolates investigated were Gram-positive cocci, catalase and oxidase negative and hydrolyzed aesculin to esculetin when cultured on BAAA. Isolates that grew at temperatures of $10^{\circ} \mathrm{C}$ and $45^{\circ} \mathrm{C}$, in the presence of $6.5 \%(\mathrm{w} / \mathrm{v})$ of $\mathrm{NaCl}$ and at $\mathrm{pH} 9.6$, were selected for further characterization. According to some authors (Collins et al., 1984; Devriese et al., 1990, 1993; Murray, 1990; Martínez-Murcia and Collins, 1991; Svec et al., 2001; Vancanneyt et al., 2004) a few species may not grow in one of these conditions, but all grow at $\mathrm{pH}$ 9.6. So, isolates that did not grow at $10^{\circ} \mathrm{C}, 45^{\circ} \mathrm{C}$ or in presence of $\mathrm{NaCl}$, but hydrolyzed aesculin and grew at $\mathrm{pH} 9.6$ were also chosen. From 1060 isolates, 782 were selected.

Since there were a large number of isolates, it was important to group them in order to reduce the number of strains for further studies and to avoid the study of multiple isolates of the same strain. A combined dendrogram for both primers M13 and D8635 was achieved. As the dendrogram was extremely large, being difficult to analyze (since it was done for all 782 isolates), an individual combined dendrogram was done for each producer, which presented a cophenetic correlation value in the range 0.6-1.0 (data not shown). Seven different profiles, in agarose gel, were obtained for the primer M13 and 11 for the primer D8635. Approximately 715 distinct bands, which ranged in size from 200 to $1400 \mathrm{bp}$, were observed with primer M13, while D8635 produced a slightly lower number of bands (6-12), which ranged in size from 200 to $3000 \mathrm{bp}$. The selection of isolates for further studies was done arbitrarily in order to have at least one isolate representative of each combined profile per producer. The number of isolates was reduced from 782 to 182 .

From 182 isolates, 76 had PCR products of $941 \mathrm{bp}$, which was a result from amplification of portions of the $d d l_{E \text {. faecalis }}$ and 44 isolates had PCR products of $550 \mathrm{bp}$ from amplification of portions of the $d d l_{\text {Enterococcus faecium. }}$ Therefore, 76 isolates were identified as E. faecalis and 44 as E. faecium. A band of $439 \mathrm{bp}$, corresponding to amplification of vanC-2/3, was observed with DNA from one isolate. vanC-2 and vanC-3 genes are almost identical (98\% identity), so this isolate could be classified as Enterococcus casseliflavus or Enterococcus flavescens. In the present work, this isolate was classified as E. casseliflavus. Although being easy and rapid to perform and quite inexpensive, this method does not allow the identification of a high number of species. DNA from 61 isolates was not amplified and consequently their identification to species level was not possible. For those isolates not identified by the method described by DuktaMalen et al. (1995), a genus-specific PCR, was used. A PCR product with $112 \mathrm{bp}$ was obtained for all the isolates, confirming that all of these isolates belong to the genus Enterococcus.

Antibiotic susceptibility of enterococcal isolates was evaluated for ampicillin, penicillin, erythromycin, vancomycin, tetracycline, chloramphenicol, ciprofloxacin, rifampicin and nitrofurantoin, in order to cover some of the known chemical and functional classes of antibiotics. The MIC $(\mu \mathrm{g} / \mathrm{ml})$, the lowest concentration without visible growth, was determined and the MIC value distributions of the 182 enterococcal isolates are listed in Table 1. Based on MICs, isolates were classified as resistant, intermediate or sensitive to each of the antibiotics investigated, according to NCCLS guidelines (2004; Table 1). It is important to emphasise that although in vitro antibiotic susceptibility testing should be used as a guide to assess microbial sensitivities to various antibiotics, it does not always reflect the in vivo situation (Blaser et al., 1995).

Enterococci are considered intrinsically resistant to $\beta$-lactam antibiotics (Kak and Chow, 2002). The results obtained in the present study are not in agreement with this generalization since all isolates were sensitive to both ampicillin and penicillin. Other authors obtained similar results (Peters et al., 2003; Ben Omar et al., 2004; McGowan-Spicer et al., 2008; Valenzuela et al., 2008). In a previous study with clinical and food isolates, Lopes et al. (2005) stated that resistance of enterococci to $\beta$-lactam antibiotics seems to be associated with clinical strains and often inaccurately generalized in the literature to the genus.

Fluoroquinolones belong to a group of antibiotics with a large spectrum of activity against Gram-negative and Gram-positive organisms, but exhibit only a weak effect on enterococci (Peters et al., 2003). In fact, of the 182 isolates investigated, only $12(6.6 \%)$ demonstrated sensitivity to ciprofloxacin. This resistance may be a result of the overwhelming use of antibiotics in human and veterinary medicine (Appelbaum and Hunter, 2000).

For human treatment, the use of chloramphenicol is low, because of its side effects and the use in animal husbandry was banned in Europe in 1994 (Peters et al., 2003). Despite this fact, and even though almost all the isolates $(172 ; 94.5 \%)$ were sensitive to 


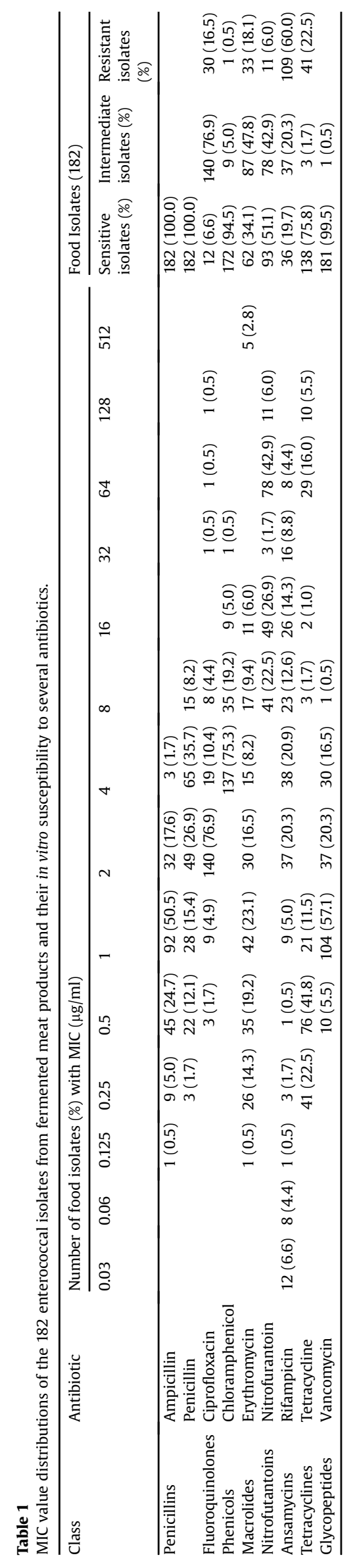

this antibiotic, one (0.5\%) isolate was resistant and nine (5.0\%) showed intermediate resistance. Other authors (Lautenbach et al., 1998; Low et al., 2001) reported the potential for the emergence of chloramphenicol resistance in enterococci.

For the antibiotic erythromycin, a high percentage of food isolates was classified as intermediate $(87 ; 47.8 \%)$ or resistant (33; 18.1\%). The same results were obtained by other authors (Mannu et al., 2003; Peters et al., 2003). The resistance to erythromycin as a representative of the macrolide antibiotics is a matter of concern, because macrolides are common substitutes used in patients with a penicillin allergy.

Nitrofurantoin is a successful antibiotic used to treat urinary tract infections caused by vancomycin-resistant enterococci and it was active against 93 (51.1\%) isolates tested. Similar results were previously reported (Hayes et al., 2003; Quiñones et al., 2005). However, 11 (6\%) isolates were resistant to this antibiotic.

A high proportion of strains were resistant to rifampicin: 109 (60.0\%) isolates were resistant. With the exception of one producer, resistant strains were isolated from products from all the producers. Rifampicin is almost exclusively used to treat tuberculosis. A very interesting study with enterococci was performed by Costa et al. (2006) in Portugal using strains isolated from municipal sewage treatment plants. A high proportion of strains from the 14 municipal treatment plants showed rifampicin resistance. One of the higher frequencies of rifampicin resistance was in Macedo de Cavaleiros. This is an interesting report in view of fact that Macedo de Cavaleiros belongs to Trás-os-Montes region, where all the fermented meat products investigated were manufactured.

The wide use of tetracycline in husbandry activities is a possible explanation for the high level of tetracycline resistance frequently found among enterococci (Busani et al., 2004; Hayes et al., 2004). In this study, $41(22.5 \%)$ isolates were resistant to this antibiotic.

Vancomycin-resistant enterococci have emerged in the last decade as a frequent cause of nosocomial infections (Rice, 2001). None of the studied isolates was resistant to vancomycin. Other authors obtained similar results for food isolates (Mannu et al. 2003; Peters et al., 2003; Majhenič et al., 2005; Messi et al., 2006). However, one isolate presented intermediate resistance to vancomycin. In these cases, according to NCCLS guidelines (2004), a screening-test for high-level aminoglycoside resistance should be done. Enterococci possess a natural low-level resistance to aminoglycosides and the high-level resistance rarely occurs (Murray, 1990). The screening-test revealed that the isolate was sensitive to gentamicin and to streptomycin. This means that these aminoglycosides could be used to treat a hypothetical infection with this isolate or even used in combination with vancomycin. Combination therapy with vancomycin plus an aminoglycoside is usually indicated for serious enterococcal infections, such as endocarditis (NCCLS, 2004).

No isolates were found to carry vanA or vanB genotype and were sensitive to vancomycin ( $\mathrm{MIC} \leq 4 \mu \mathrm{g} / \mathrm{ml}$ ). The only isolate, showing moderate resistance to vancomycin ( $\mathrm{MIC}=8 \mu \mathrm{g} / \mathrm{ml}$ ), was positive for the vanC-2/C3 gene, and was identified as E. casseliflavus; vanC type is an intrinsic property of motile enterococci (Navarro and Courvalin, 1994). The presence of the vanA gene in Enterococcus spp. is associated with high vancomycin resistance (MIC $=64$ $>1000 \mu \mathrm{g} / \mathrm{ml}$ ), while $\operatorname{vanB} \quad(\mathrm{MIC}=4-1024 \mu \mathrm{g} / \mathrm{ml}$ ) and $\operatorname{vanC}$ (MIC $=2-32 \mu \mathrm{g} / \mathrm{ml}$ ) are associated with medium to low levels of vancomycin resistance, respectively (Cetinkaya et al., 2000). A good correlation was observed between the MIC values for vancomycin and the absence of vanA and vanB genes in Enterococcus isolates.

Resistance to multiple antibiotics was observed. All isolates were resistant to at least 2 antibiotics, with the exception of 11 isolates that were resistant to three antibiotics and 4 isolates that 
Table 2

Multiple resistance phenotypes among food isolates.

\begin{tabular}{ll}
\hline Antimicrobial resistance pattern & Number of food isolates (\%) \\
\hline Cip Rif & $14(7.7)$ \\
Tet Rif & $16(8.8)$ \\
Eri Rif & $21(11.5)$ \\
Cip Tet & $2(1.1)$ \\
Nit Rif & $1(0.5)$ \\
Eri Nit & $2(1.1)$ \\
Nit Rif Tet & $3(1.6)$ \\
Cip Rif Tet & $2(1.1)$ \\
Cip Nit Tet & $1(0.5)$ \\
Cip Eri Rif & $4(2.2)$ \\
Eri Rif Tet & $1(0.5)$ \\
Eri Nit Rif Tet & $1(0.5)$ \\
Cip Eri Rif Tet & $2(1.1)$ \\
Cip Eri Chl Rif & $1(0.5)$ \\
\hline
\end{tabular}

Cip (Ciprofloxacin), Chl (Chloramphenicol), Eri (Erythromycin), Nit (Nitrofurantoin), Rif (Rifampicin), Tet (Tetracycline).

were resistant to four antibiotics. Profiles of multiple resistance of isolates to the selected antimicrobials are presented in Table 2.

Resistances to several antibiotics (tetracycline, rifampicin, erythromycin, ciprofloxacin, nitrofurantoin and chloramphenicol) as well as sensitivity to ampicillin and penicillin were also found in recent studies with enterococci, such as the studies of McGowanSpicer et al. (2008), Valenzuela et al. (2008) and Valenzuela et al. (2009). In a particular study with enterococci isolated from poultry in Portugal, Poeta et al. (2006) observed that a high proportion of strains were resistant to tetracycline (97\%), erythromycin (88\%); lower proportions were resistant to chloramphenicol (16\%) and ampicillin (10\%). In the production of fermented products such as Alheira, poultry meats are used in their manufacture and interestingly, with the exception of ampicillin, similar resistance patterns were observed in the current study.

Some differences in resistance rates could be associated with the enterococcal species. Of $E$. faecalis isolates, $38.2 \%$ were resistant to tetracycline, while only $2.3 \%$ of the E. faecium were resistant. More $E$. faecium strains were resistant to erythromycin (36.4\%) than $E$. faecalis isolates (9.2\%). Both species were observed to exhibit resistance to rifampicin as well as similar sensitivity to other antibiotics.

A consequence of nosocomial infections associated with enterococci and the difficulty of treating such infections due to antibiotic resistance, are matters of concern. The presence of other resistances and the ability for enterococci to acquire resistance genes by natural-conjugation gene transfer processes is such a problem. In a previous study (data not shown) the occurrence of virulence factors in these enterococci, emphasized the importance of the current study. Overall, from the clinical perspective, assuming that an infection by these food isolates is possible, their susceptibility to antibiotics commonly used to treat enterococcal diseases, such as penicillins and vancomycin (last resort for treatment of multiple-resistant enterococcal infections), is a positive indication for treatment.

\section{Acknowledgements}

The authors are grateful to Fundação para a Ciência e a Tecnologia (FCT/FEDER Project POCTI/AGG/39587/2001), which supported the isolation of strains studied in this work.

The authors would also like to acknowledge Dr. Paul Gibbs for editing the English language.

\section{References}

Andrighetto, C., Zampese, L., Lombardi, A., 2001. RAPD-PCR characterization of lactobacilli isolated from artisanal meat plants and traditional fermented sausages of Veneto region (Italy). Lett. Appl. Microbiol. 33, 26-30.
Appelbaum, P.C., Hunter, P.A., 2000. The fluoroquinolone antibacterials: past, present and future perspectives. Int. J. Antimicrob. Agents 16, 5-15.

Arthur, M., Molinas, C., Depardieu, F., Courvalin, P., 1993. Characterization of Tn1546, a tn3-related transposon conferring glycopeptide resistance by synthesis of depsipeptide peptidoglycan precursors in Enterococcus faecium BM4147. J. Bacteriol. 175, 117-127.

Baumgartner, A., Kueffer, M., Rohner, P., 2001. Occurrence and antibiotic resistance of enterococci in various ready-to-eat foods. Arch. Lebensm. Hyg. 52, 1-24.

Ben Omar, N., Castro, A., Lucas, R., Abriouel, H., Yousif, N.M.K., Franz, C.M.A.P., Holzapfel, W.H., Pérez-Pulido, R., Martínez-Cañamero, Gálvez, A., 2004. Functional and safety aspects of enterococci isolated from different Spanish foods. Syst. Appl. Microbiol. 27, 118-130.

Blaser, J., Vergères, P., Widmer, A.F., Zimmerli, W., 1995. In vivo verification of in vitro model of antibiotic treatment of device-related infection. Antimicrob. Agents Chemother. 39, 1134-1139.

Borgen, K., Sørum, M., Wasteson, Y., Kruse, H., 2001. VanA-type vancomycin-resistant enterococci (VRE) remain prevalent in poultry carcasses 3 years after avoparcin was banned. Int. J. Food Microbiol. 64, 89-94.

Busani, L., Del Grosso, M., Paladini, C., Graziani, C., Pantosti, A., Biavasco, F. Caprioli, A., 2004. Antimicrobial susceptibility of vancomycin-susceptible and -resistant enterococci isolated in Italy from raw meat products, farm animals, and human infections. Int. J. Food Microbiol. 97, 17-22.

Cetinkaya, Y., Falk, P., Mayhall, C.G., 2000. Vancomycin-resistant enterococci. Microbiol. Rev. 13, 686-707.

Collins, M.D., Jones, D., Farrow, J.A.E., Kilpper-Bälz, R., Schleifer, K.H., 1984. Enterococcus avium nom. rev., comb. nov.; E. casseliflavus nom. rev., comb. nov.; E. durans nom. rev., comb. nov.; E. gallinarum comb. nov.; and E. malodoratus sp. nov. Int. J. Syst. Bacteriol. 34, 220-223.

Corpet, D.E., 1998. Antibiotic resistant bacteria in human food. Rev. Méd. Vét. 149, 819-822.

Costa, P.M., Vaz-Pires, P., Bernardo, F., 2006. Antimicrobial resistance in Enterococcus spp. isolated in inflow, effluent and sludge from municipal sewage water treatment plants. Water Res. 40, 1735-1740.

Del grosso, M., Caprioli, A., Chinzari, P., Fontana, M.C., Pezzotti, G., Manfrin, A., Giannatale, E.D., Goffredo, E., Pantosti, A., 2000. Detection and characterization of vancomycin-resistant enterococci in farm animals and raw meat products in Italy. Microb. Drug Resist. 6, 313-318.

Destro, M.T., Leitão, M.F.F., Farber, J.M., 1996. Use of molecular typing methods to trace the dissemination of Listeria monocytogenes in a shrimp processing plant. Appl. Environ. Microbiol. 62, 705-711.

Devriese, L.A., Ceyssens, K., Rodrigues, U.M., Collins, M.D., 1990. Enterococcus columbae, a species from pigeon intestines. FEMS Microbiol. Lett. 71, 247-252.

Devriese, L.A., Pot, B., Collins, M.D., 1993. Phenotypic identification of the genus Enterococcus and differentiation of phylogenetically distinct enterococcal species and species groups. J. Appl. Bacteriol. 75, 399-408.

Dukta-Malen, S., Evers, S., Courvalin, P., 1995. Detection of glycopeptide resistance genotypes and identification to the species level of clinically relevant enterococci by PCR. J. Clin. Microbiol. 33, 24-27 (Erratum, 33:1434).

Endtz, H.P., Van den Braak, N., Verbrugh, H.A., Van Bekum, A., 1999. Vancomycin resistance status quo and quo vadis. Eur. J. Clin. Microbiol. Infect. Dis. 18, 683-690.

Ferreira, V., Barbosa, J., Vendeiro, S., Mota, A., Silva, F., Monteiro, M.J., Hogg, T., Gibbs, P., Teixeira, P., 2006. Chemical and microbiological characterization of Alheira: a typical Portuguese fermented sausage with particular reference to factors relating to food safety. Meat Sci. 73, 570-575.

Ferreira, V., Barbosa, J., Silva, J., Vendeiro, S., Mota, A., Silva, F., Monteiro, M.J., Hogg, T., Gibbs, P., Teixeira, P., 2007. Chemical and microbiological characterization of "Salpicão de Vinhais" and "Chouriça de Vinhais": traditional dry sausages produced in the North of Portugal. Food Microbiol. 24, 618-623.

Fines, M., Perichon, B., Reynolds, P., Sahm, D.F., Courvalin, P., 1999. VanE, a new type of acquired glycopeptide resistance in Enterococcus faecium BM4405. Antimicrob. Agents Chemother. 43, 2161-2164.

Gomes, B.C., Esteves, C.T., Palazzo, I.C.V., Darini, A.L.C., Felis, G.E., Sechi, L.A. Franco, B.D.G.M., De Martinis, E.C.P., 2008. Prevalence and characterization of Enterococcus spp. isolated from Brazilian foods. Food Microbiol. 25, 668-675.

Hayes, J.R., English, L.L., Carter, P.J., Proescholdt, T., Lee, K.Y., Wagner, D.D. White, D.G., 2003. Prevalence and antimicrobial resistance of Enterococcus species isolated from retail meats. Appl. Environ. Microbiol. 69, 7153-7160.

Hayes, J.R., English, L.L., Carr, L.E., Wagner, D.D., Joseph, S.W., 2004. Multiple-antibiotic resistance of Enterococcus spp. isolated from commercial poultry production environments. Appl. Environ. Microbiol. 70, 6005-6011.

Houben, J.H., 2003. The potential of vancomycin-resistant enterococci to persist in fermented and pasteurized meat products. Int. J. Food Microbiol. 88, 11-18.

Hummel, A., Holzapfel, W.H., Franz, C.M.A.P., 2007. Characterisation and transfer of antibiotic resistance genes from enterococci isolated from food. Syst. Appl. Microbiol. 30, 1-7.

Kak, V., Chow, J.W., 2002. Acquired antibiotic resistances in enterococci. In: Gilmore, M.S. (Ed.), The Enterococci: Pathogenesis, Molecular Biology and Antibiotic Resistance. American Society for Microbiology, Washington, DC, pp. 355-383.

Ke, D., Picard, F.J., Martineau, F., Menard, C., Roy, P.H., Ouellette, M., Bergeron, M.G., 1999. Development of a PCR assay for rapid detection of enterococci. J. Clin. Microbiol. 37, 3497-3503.

Klein, G., Pack, A., Bonaparte, C., Reuter, G., 1998. Taxonomy and physiology of probiotic lactic acid bacteria. Int. J. Food Microbiol. 41, 103-125. 
Koluman, A., Akanb, L.S., Çakiroğlub, F.P., 2009. Occurrence and antimicrobial resistance of enterococci in retail foods. Food Control 20, 281-283.

Lautenbach, E., Schuster, M.G., Wilker, W.B., Brennan, P.J., 1998. The role of chloramphenicol in the treatment of bloodstream infection due to vancomycinresistant Enterococcus. Clin. Infect. Dis. 27, 1259-1265.

Leclercq, R., 1997. Enterococci acquire new kinds of resistance. Clin. Infect. Dis. 24 (Suppl. 1), S80-S84.

Lopes, M.F.S., Ribeiro, T., Abrantes, M., Marques, J.J.F., Tenreiro, R., Crespo, M.T.B. 2005. Antimicrobial resistance profiles of dairy and clinical isolates and type strains of enterococci. Int. J. Food Microbiol. 103, 191-198.

Low, D.B., Keller, N., Barth, A., Jones, R.N., 2001. Clinical prevalence antimicrobial susceptibility and geographic resistance patterns of enterococci: results from the SENTRY antimicrobial surveillance program. Clin. Infect. Dis. 32, 133-145.

Majhenič, A.Č., Rogelj, I., Perko, B., 2005. Enterococci from Tolminc cheese: population structure, antibiotic susceptibility and incidence of virulence determinants. Int. J. Food Microbiol. 102, 239-244.

Mannu, L., Paba, A., Daga, E., Comunian, R., Zanetti, S., Duprè, I., Sechi, L.A., 2003. Comparison of the incidence of virulence determinants and antibiotic resistance between Enterococcus faecium strains of dairy, animal and clinical origin. Int. J. Food Microbiol. 88, 291-304.

Martínez-Murcia, A.J., Collins, M.D., 1991. Enterococcus sulfureus, a new yellowpigmented Enterococcus species. FEMS Microbiol. Lett. 64, 69-74.

McGowan-Spicer, L.L., Fedorka-Cray, P.J., Frye, J.G., Meinersmann, R.J., 2008. Antimicrobial resistance and virulence of Enterococcus faecalis isolated from retail food. J. Food Prot. 71, 760-769.

McKessar, S.J., Berry, A.M., Bell, J.M., Turnidge, J.D., Paton, J.C., 2000. Genetic characterization of vanG, a novel vancomycin resistance locus of Enterococcus faecalis. Antimicrob. Agents Chemother. 44, 3224-3228.

Messi, P., Guerrieri, E., Niederhäusern, S., Sabia, C., Bondi, M., 2006. Vancomycinresistant enterococci (VRE) in meat and environmental samples. Int. J. Food Microbiol. 107, 218-222.

Moellering, R.C., 1990. The enterococci: an enigma and a continuing therapeutic challenge. Eur. J. Clin. Microbiol. Infect. Dis. 9, 73-74.

Moellering, R.C., 1991. The garrod lecture. The Enterococcus: a classic example of the impact of antimicrobial resistance on therapeutic options. J. Antimicrob. Chemother. 28, 1-12.

Moellering, R.C., Gold, H.S., 1996. Antimicrobial-drug resistance. N. Engl. J. Med. 335, $1445-1453$.

Moellering, R.C., Krogstad, D.J., 1979. In: Schlessinger, D. (Ed.), Antibiotic Resistance in Enterococci. American Society for Microbiology, Washington DC, pp. 293-298.

Morrison, D., Woodford, N., Cookson, B., 1997. Enterococci as emerging pathogens of humans. J. Appl. Microbiol. Symp. (Suppl. 83), 89-99.

Murray, B.E., 1990. The Life and Times of the Enterococcus. Clin. Microbiol. Rev. 3 , 46-65.

Navarro, F., Courvalin, P., 1994. Analysis of genes encoding D-alanine:D-alanine ligase-related enzymes in Enterococcus casseliflavus and Enterococcus flavescens. Antimicrob. Agents Chemother. 38, 1788-1793.

National Committee for Clinical Laboratory Standards, 2004. Approved Standard M7-A6. Performance Standards for Antimicrobial Susceptibility Testing, 14th ed., vol. 24(1) January.

Nilsson, J., Svensson, B., Ekelund, K., Christiansson, A., 1998. A RAPD-PCR method for large-scale typing of Bacillus cereus. Lett. Appl. Microbiol. 27, 168-172.
Ogier, J., Serror, P., 2008. Safety assessment of dairy microorganisms: the Enterococcus genus. Int. J. Food Microbiol. 126, 291-301.

Peters, J., Mac, K., Wichmann-Schauer, H., Klein, G., Ellerbroek, L., 2003. Species distribution and antibiotic resistance patterns of enterococci isolated from food of animal origin in Germany. Int. J. Food Microbiol. 88, 311-314.

Pitcher, D.G., Saunders, N.A., Owen, R.J., 1989. Rapid extraction of bacterial genomic DNA with guanidium thiocyanate. Lett. Appl. Microbiol. 8, 151-156.

Poeta, P., Costa, D., Rodrigues, J., Torres, C., 2006. Antimicrobial resistance and the mechanisms implicated in faecal enterococci from healthy humans, poultry and pets in Portugal. Int. J. Antimicrob. Agents 27, 131-137.

Psoni, L., Kotzamanides, C., Andrighetto, C., Lombardi, A., Tzanetakis, N., LitopoulouTzanetaki, E., 2006. Genotypic and phenotypic heterogeneity in Enterococcus isolates from Batzos, a raw goat milk cheese. Int. J. Food Microbiol. 109, 109-120.

Quednau, M., Ahrné, S., Petersson, A.C., Molin, G., 1998. Antibiotic-resistant strains of Enterococcus isolated from Swedish and Danish retailed chicken and pork. J. Appl. Microbiol. 84, 1163-1170.

Quiñones, D., Goñi, P., Rubio, M.C., Duran, E., Gómez-Lus, R., 2005. Enterococci spp. isolated from Cuba: species frequency of occurrence and antimicrobial susceptibility profile. Diagn. Microbiol. Infect. Dis. 51, 63-67.

Rice, L.B., 2001. Emergence of vancomycin-resistant enterococci. Emerg. Infect. Dis. 7, 183-187.

Sabia, C., De Niederhäusern, S., Guerrieri, E., Messi, P., Anacarso, I., Manicardi, G., Bondi, M., 2008. Detection of bacteriocin production and virulence traits in vancomycin-resistant enterococci of different sources. J. Appl. Microbiol. 104 970-979.

Schwarz, F.V., Perreten, V., Teuber, M., 2001. Sequence of the $5 \mathrm{~kb}$ conjugative multiresistance plasmid pRE25 from Enterococcus faecalis RE25. Plasmid 46, 170-187.

Son, R., Nimita, F., Rusul, G., Nasreldin, E., Samuel, L., Nishibuchi, M., 1999. Isolation and molecular characterization of vancomycin-resistant Enterococcus faecium in Malaysia. Lett. Appl. Microbiol. 29, 118-122.

Svec, P., Devriese, L.A., Sedlacek, I., Baele, M., Vancanneyt, M., Haesebrouck, F. Swings, J., Doskar, J., 2001. Enterococcus haemoperoxidus sp. nov. and Enterococcus moraviensis sp. nov., isolated from water. Int. J. Syst. Evol. Microbiol. 51, 1567-1574.

Teuber, M., Meile, L., Schwarz, F., 1999. Acquired antibiotic resistance in lactic acid bacteria from food. Antonie van Leeuwenhoek 76, 115-137.

Valenzuela, A.S., Ben-Omar, N., Abriouel, H., López, R.L., Ortega, E., Cañamero, M.M., Gálvez, A., 2008. Risk factors in enterococci isolated from foods in Morocco: determination of antimicrobial resistance and incidence of virulence traits. Food Chem. Toxicol. 46, 2648-2652.

Valenzuela, A.S., Ben-Omar, N., Abriouel, H., López, R.L., Veljovic, K. Cañamero, M.M., Topisirovic, M.K.L., Gálvez, A., 2009. Virulence factors, antibiotic resistance, and bacteriocins in enterococci from artisan foods of animal origin. Food Control 20, 381-385.

Van den Braak, N., Van Belkum, A., Van Keulen, M., Vliegenthart, J., Verbrugh, H.A. Endtz, H.P., 1998. Molecular characterization of vancomycin-resistant enterococci from hospitalised patients and poultry products in the Netherlands. J. Clin. Microbiol. 36, 1927-1932.

Vancanneyt, M., Zamfir, M., Devriese, L.A., Lefebvre, K., Engelbeen, K. Vandemeulebroecke, K., Amar, M., De Vuyst, L., Haesebrouck, F., Swings, J., 2004 Enterococcus saccharominimus sp. nov., from dairy products. Int. J. Syst. Evol. Microbiol. 54, 2175-2179. 